\title{
TraduÇão de: Discurso sobre Cícero, de Montesquieu
}

\author{
[TÍTUlO ORIGINAL: DisCOURS SUR CiCÉRON]
}

\author{
Igor Moraes Santos * \\ Universidade Federal de Minas Gerais, Brasil
}

\begin{abstract}
Resumo: Em Discurso sobre Cícero, um ainda jovem Montesquieu descreve em termos breves a vida e a obra do cônsul romano. Com predomínio de um tom laudatório, aponta qualidades e, mesmo fazendo críticas, não deixa de reconhecer a importância de Cícero como homem político e homem de letras. Este é um texto que pode contribuir para a interpretação sobre os fundamentos clássicos de seus principais trabalhos. Tradução inédita para português acompanhada de nota introdutória.
\end{abstract}

Palavras-chave: Montesquieu; Cícero;
Abstract: In Discourse on Cicero, a still young Montesquieu describes in brief terms the life and work of the Roman consul. With a predominance of a laudatory tone, he points out qualities and, even criticizing, he recognizes the importance of Cicero as a politician and a man of letters. This is a text that can contribute to the interpretation of the classical foundations of his main works. First translation into Portuguese with an introductory note.

KEYwORDS: Montesquieu; Cicero; discourse discurso

\section{Nota do Tradutor}

"Cícero, segundo eu, é um dos grandes espíritos que jamais existiram." Esta frase, presente em um entre vários pensées que não ganharam as páginas das grandes obras, revela como o cônsul, filósofo e orador romano era visto por Charles-Louis de Secondat, Barão de La Brède e de Montesquieu.

Ao longo do Medievo e da Modernidade, as orações de Cícero contribuíram sobremaneira para o estudo do latim e para manter viva uma áurea de admiração em torno de Roma. Diversas de suas obras filosóficas, no entanto, ficaram perdidas por muitos séculos e, no tempo de Montesquieu, poucos dos escritos políticos eram acessíveis, em especial o De re publica e o De legibus, redescobertos em manuscritos mais ou menos fragmentários apenas nos Oitocentos.

De todo modo, desde cedo Montesquieu reconheceu a importância do Arpinata e, por isso, esforçou-se para estudar as obras e os extratos disponíveis. Se nas Considérations sur les causes de la grandeur des Romains et de leur décadence pouco

* Doutorando em Direito pela Universidade Federal de Minas Gerais. Pesquisador com enfoque em Filosofia do Direito, com trabalhos publicados sobre Cícero e Montesquieu. m@ilto: santosigormoraes@gmail.com 
percebemos de Cícero, várias são as referências explícitas em De l'esprit des lois. Contudo, onde mais sentimos o apreço do magistrado de Bourdeaux são em textos inéditos, manuscritos inacabados ou pensamentos esparsos, publicados somente depois de sua morte, sem contar um tratado perdido sobre os deveres. Mesmo nessas passagens escassas, complementadas pelas riquíssimas notas de estudo sobre a obra ciceroniana, trazidas à luz apenas no início dos anos $2000^{2}$, é possível identificar o que, ainda em juventude, Montesquieu encantadoramente expressou no Discours sur Cicéron.

Nesse panegírico, ocultado do público por tomá-lo como excessivamente laudatório, o autor perpassa em breves palavras a vida e a obra do político romano. Nelas são entrevistos qualidades e defeitos. Por um lado, Cícero é caracterizado como o libertador da República, garante da liberdade, fiel aos deveres como cidadão mesmo nos momentos mais atribulados e desafiadores. Por outro, embora grande intelectual, mais trabalhou para destruir erros do que para descobrir verdades. Sobre este último aspecto, Fott $^{3}$ ressalta como Montesquieu defende a superioridade dos modernos mais sábios em relação aos mais doutos antigos, repercutindo a célebre Querelle des Anciens et des Modernes sob o enfoque do mais recente espírito científico. Não obstante, cremos também ter nessa postura o desvelamento da limitada consciência do ceticismo acadêmico em Cícero naquela época, pois, se levado em consideração, é possível compreender algumas de suas atitudes especulativas: sendo incerto ao homem o conhecimento efetivo da verdade, resta somente buscar a probabilidade do que ela seja, afastando, precisamente, os erros, para assim encontrar o verossímil.

Montesquieu não é ingrato com o Cícero filósofo, tão desprezado pela tradição, que reduz a mero reprodutor de ideias dos grandes pensadores gregos, como Platão e Panécio, concepção ainda hoje recorrente. Ele também defende a sua originalidade, a ponto de indicá-lo como mais expressivo nos trabalhos teóricos, onde não possuía tantos rivais quanto na eloquência. Mas por esta última se fez grande personagem da história. E Montesquieu é tributário de sua contribuição para o republicanismo, concepção política pela qual alimenta um interesse inicial, posteriormente redimensionado com a percepção dos limites das repúblicas em tempos recentes, como vemos em sua magnus opus.

Embebendo a interpretação com elogios contrapostos a críticas por sua debilidade como homem público e homem de letras, o olhar de Montesquieu sobre Cícero nesse Discours pode ser resumida pela frase que encerra o anteriormente mencionado pensée 773: "A alma sempre bela quando não era fraca."

\section{TradUÇão ${ }^{4}$}

[I] Cícero ${ }^{5}$ é, de todos os antigos, aquele que teve o maior mérito pessoal, e ao qual mais gostaria de me parecer; não há qualquer um que tenha firmado as mais belas e as mais grandes características, que [5] mais tenha amado a glória, que tenha obtido uma mais sólida e que a teve por caminhos menos percorridos.

A leitura de suas obras não eleva menos o coração que o espírito: sua eloquência é totalmente grande, totalmente majestosa, totalmente heroica. Deve-se vê-lo [10] triunfar sobre Catilina; deve-se vê-lo levantar-se contra Antônio; deve-se vê-lo, enfim, chorar pelos restos deploráveis de uma liberdade moribunda. Seja contando suas ações, seja relatando aquelas dos grandes homens que combateram pela República, ele se embriaga com sua [15] glória e com a daqueles. A ousadia de suas expressões faz entrar na vivacidade de seus sentimentos. Eu sinto que ele me arrasta em seus transportes e me leva embora em seus movimentos. Que retratos aqueles que faz [II] dos Brutos, dos 
Cássios, dos Catões! Que fogo, que vivacidade, que rapidez, que torrente de eloquência! Para mim, não sei a quem gostaria mais de parecer, ou ao herói, ou ao panegirista.

[5] Se ele exalta às vezes seus talentos com demasiada pompa, não faz mais do que expressar a mim o que já me fizera sentir; ele me alerta sobre os elogios que lhe são devidos. Não me irrita ser advertido de que esse não é um simples orador que fala, mas o libertador da pátria e o [10] defensor da liberdade.

Ele não merece menos o título de filósofo do que o de orador romano. Pode-se dizer mesmo que ele se destacou mais no Liceu do que sobre a tribuna: ele é original em seus livros de filosofia, mas teve [15] vários rivais em sua eloquência.

Ele é o primeiro, entre os romanos, que tirou a filosofia das mãos dos sábios, e a liberou dos embaraços de uma língua estrangeira. Ele a tornou comum a todos os homens, como razão, e, [20] nos aplausos que recebeu, a gente de letras encontrou-se de acordo com o povo. Não posso suficientemente admirar a profundidade de seus raciocínios em um tempo no qual os sábios não se distinguiam que pela bizarrice de suas vestimentas. [25] Gostaria somente que ele tivesse vindo em um século mais esclarecido, e que ele tivesse podido empregar para descobrir as verdades esses afortunados talentos, que não lhe serviram mais que para destruir os erros. Deve-se reconhecer que ele deixou um terrível vazio na filosofia: ele destruiu tudo [30] o que havia sido imaginado até então; teve de recomeçar, e imaginar de novo; o gênero humano [III] regressou, por assim fizer, à infância, e foi entregue aos primeiros princípios.

Que prazer vê-lo, em seu livro Da natureza dos deuses, fazer passar em revista todos os séquitos, [5] confundir todos os filósofos, e marcar cada preconceito com alguma desonra! Âs vezes combate esses monstros; às vezes joga com a filosofia. Os campeões que ele introduz destroem-se a si mesmos; aquele é confundido com este, que [10] se encontra derrotado a seu turno. Todos esses sistemas se desvanecem uns diante dos outros, e não resta, no espírito do leitor, que o desprezo pelos filósofos e a admiração pela crítica.

Com tal satisfação vemo-lo, em seu [15] livro Da adivinhação, liberar o espírito dos romanos do jugo ridículo dos arúspices e das regras dessa arte, que eram o opróbio da teologia pagã, que foi estabelecida no começo, pela política dos magistrados, entre os povos grosseiros, e [20] enfraquecida, pela mesma política, quando se tornaram mais esclarecidos.

Às vezes ele nos desvela os charmes da amizade e nos faz sentir todas as suas delícias; às vezes ele nos faz ver as vantagens de uma idade que a razão esclarece, [25] e que nos salva da violência das paixões.

Às vezes, formando nossos costumes e nos mostrando a extensão de nossos deveres, ensina-nos o que é o honesto e o que é o útil; o que devemos à sociedade, o que devemos a [30] nós mesmos; o que devemos fazer na qualidade de pais de família ou na qualidade de cidadãos.

[IV] Os seus costumes eram mais austeros do que seu espírito. Ele comportou-se em seu governo da Cilícia com o desinteresse dos Cincinatos, dos Camilos, dos Catões. Mas a sua virtude, que não tinha nada de selvagem, [5] não o impediu em absoluto de gozar da polidez de seu século. Percebe-se, em suas obras de moral, um ar de júbilo e um certo contentamento de espírito que os filósofos medíocres não conhecem em absoluto. Ele não dá em absoluto preceitos; mas [10] os faz sentir. Ele não nos excita à virtude; mas nos atrai a ela. Leia as suas obras, e desgostará para sempre de Sêneca e de seus semelhantes, pessoas mais enfermas que aquelas a quem queriam curar, mais desesperadas que aquelas a quem consolam, mais tiranizadas [15] pelas paixões que 
aquelas a quem querem libertar.

Algumas pessoas, acostumadas a medir todos os heróis sobre o de Quinto Cúrcio $^{6}$, fizeram de Cícero uma ideia bem falsa; eles olharam-no [20] como um homem débil e tímido, e lhe fizeram uma reprovação que Antônio, seu maior inimigo, jamais lhe fizera. Ele evitava o perigo, porque ele o conhecia; mas ele não o conhecia mais, porque não podia evitá-lo. Esse grande homem sempre subordinou [25] todas as suas paixões, seu temor e sua coragem, à sabedoria e à razão. Ouso mesmo a dizer: não há talvez nenhum homem, entre os romanos, que deu os maiores exemplos de força e coragem.

[30] Não é verdade que declamar a Segunda Filípica diante de Antônio, era correr para uma morte [V] certa? Era fazer um generoso sacrifício de sua vida em favor de sua glória ofendida? Admiremos então a coragem e a ousadia do orador ainda mais que sua eloquência. Consideremos Antônio, o mais [5] poderoso entre os homens, Antônio, o mestre do mundo, Antônio, que ousava a tudo e que podia tudo o que ousava, em um Senado que estava cercado por seus soldados, e onde ele era mais rei do que cônsul; consideremo-lo, digo, coberto de confusão e de ignomínia, [10] fulminado, aniquilado, obrigado a ouvir o que há de mais humilhante da boca de um homem que teria podido tirar milhares de vidas.

Ademais, não foi somente à frente de um exército que ele teve necessidade de sua firmeza e de sua [15] coragem; as dificuldades que ele teve de sofrer, em tempos tão difíceis para as gentes de bem, renderam-lhe a morte sempre presente. Todos os inimigos da República foram os seus; os Verres, os Clódios, os Catilinas, os Césares, os Antônios, enfim, todos os [20] celerados de Roma declararam-lhe a guerra.

É verdade que houve ocasiões onde a força de seu espírito parecia abandonarlhe: quando ele viu Roma devastada por tantas facções, ele se entregou à dor, ele se deixou abater, e sua filosofia foi [25] menos forte do que seu amor pela República.

Nessa famosa guerra que decidiu o destino do Universo, ele tremia por sua pátria; ele via César aproximar-se com um exército que tinha ganhado mais batalhas do que tinha de legiões. [30] Mas qual foi a sua dor quando viu que Pompeu abandonava a Itália e deixaria Roma exposta à [VI] fúria dos rebeldes! "Após uma tal covardia, disse ele, eu não podia mais estimar esse homem, que, bem longe do se exilar de sua pátria, como fez, deveria morrer sobre as muralhas de Roma e ser enterrado sob as suas [5] ruínas."

Cícero, que estudava há muito tempo os projetos de César, tivesse infligido a este ambicioso o destino de Catilina, se sua prudência tivesse sido escutada: "Se meus conselhos tivessem sido seguidos, disse esse orador a Antônio, [10] a República floriria hoje, e tu estarias no nada. Eu fui da opinião de que não deveria em absoluto continuar César o governo das Gálias para além dos cinco anos. Eu fui da opinião ainda de que, enquanto ele estivesse ausente, não se deveria em absoluto admiti-lo a pleitear [15] o consulado. Se tivesse sido mais feliz em persuadir um ou outro, nós não seríamos jamais jogados ao abismo onde estamos hoje. Mas, quando eu vi (continua ele) que Pompeu tinha deixado a República a César, quando percebi que ele começava [20] muito tarde a sentir os males que eu tinha previsto há muito tempo, não cessei então de falar sobre compromisso e não poupei nada para reunir os espíritos."7

Pompeu tendo abandonado a Itália, Cícero, que, [25] como ele mesmo disse, sabia bem que ele deveria fugir, mas ignorava quem deveria seguir, permaneceu ainda por algum tempo. César reuniu-se com ele e queria obrigá-lo, por rogos e por ameaças, a aderir a seu partido. Mas esse republicano rejeitou suas [30] propostas com tanto desprezo quanto orgulho. Quando o partido da liberdade fora destruído, ele [VII] submeteu-se a ele com todo o Universo; ele não fez em absoluto uma resistência inútil; 
ele não fez em absoluto como Catão, que abandonou covardemente a República com a vida; ele se reserva para tempos mais felizes, e procura [5] na filosofia os consolos que os outros apenas encontraram na morte.

Ele retira-se a Tusculum para procurar a liberdade que sua pátria havia perdido. Esses campos não foram nunca tão gloriosamente férteis; nós devemos a eles [10] essas belas obras que serão admiradas por todos os séquitos e em todas as revoluções da filosofia.

Mas, quando os conjurados cometeram essa grande ação que espanta ainda hoje os [15] tiranos, Cícero saiu como da tumba, e o seu sol, que o astro de Julho ${ }^{8}$ tinha eclipsado, retomaram uma nova luz. Bruto, todo coberto de sangue e de glória, mostrava ao povo o punhal e a liberdade, gritou: "Cícero!" E, seja que o chamou em sua [20] ajuda, seja que quis ${ }^{9}$ felicitá-lo pela liberdade que vinha devolver, seja enfim que esse novo libertador da pátria se declarou seu rival, ele fez em uma só palavra o mais magnífico elogio que um mortal jamais recebeu.

[25] Cícero uniu-se imediatamente a Bruto; os perigos não o espantaram em absoluto. César vivia ainda no coração dos soldados; Antônio, que era o herdeiro de sua ambição, tinha nas suas mãos a autoridade consular. Tudo isso não o impediu em absoluto de se declarar, e, por [VIII] sua autoridade e seu exemplo, ele determina o Universo era ainda incerto se ele deveria considerar Bruto como um parricida ou como o libertador da pátria.

Mas as liberalidades que César tinha feito aos [5] romanos por seu testamento foram para eles novas correntes. Antônio arengou a esse povo avaro, e, mostrando-lhe o vestido ensanguentado de César, emocionou-se tão fortemente que colocou fogo nas casas dos conjurados. Bruto e Cássio, forçados a abandonar a sua [10] ingrata pátria, tiveram apenas esse meio para se furtarem aos insultos de uma população tão furiosa quanto cega.

Antônio, tornando-se mais audaz, usurpou em Roma mais autoridade do que fizera o próprio César. [15] Ele apossou-se dos dinheiros públicos, vendeu as províncias e as magistraturas, fez guerra nas colônias romanas, violou enfim todas as leis. Orgulhoso do sucesso de sua eloquência, ele não temia mais aquela de Cícero, declamou contra ele em pleno Senado; mas [20] ficou bem surpreso de encontrar ainda em Roma um romano.

Pouco depois, Otávio fez esse infame tratado no qual Antônio, pelo preço de sua amizade, exigiu a cabeça de Cícero. Nunca a guerra foi mais funesta [25] para a República que essa indigna reconciliação, onde se imolou por vítimas aqueles que tinham tão gloriosamente a defendido.

O detestável Popílio justificava assim, em Sêneca, a morte de Cícero: que esse crime tão odioso foi o crime de Antônio, que tinha comandado, não dele, Popílio, que obedecera; que a proscrição de Cícero fora de morrer, [IX] aquela de Popílio de tirar-lhe a vida; que não foi maravilhoso que fora forçado a matá-lo, pois Cícero, [5] o primeiro de todos os romanos, fora constrangido a perder a cabeça ${ }^{10}$.

\section{Notas}

1 MONTESQUIEU. Pensées I, 773. Cf. DORNIER, Carole (ed.). Montedite: Édition critique des Pensées de Montesquieu. Caen: Presses Universitaires de Caen, 2013. Disponível em: http://www.unicaen.fr/services/puc/sources/Montesquieu. Acesso em 08 abr. 2018.

2 VOLPILHAC-AUGER, Catherine. La tentation de l'édition: Montesquieu annotateur de Cicéron. Astérion, n. 11, jul. 2013. Disponível em: http://journals.openedition.org/asterion/2444. Acesso em 06 abr. 2018. 
3 FOTT, David. Preface to translation of Montesquieu's "Discourse on Cicero". Political Theory, v. 30, n. 5 , p. $728-732$, out. 2002.

4 A presente tradução valeu-se do texto original, conforme publicado em MONTESQUIEU, Charles-Louis de Secondat, Baron de La Brède et de. Discours sur Cicéron. In: Mélanges inédits de Montesquieu. Bourdeaux: G Gounouilhou; Paris: J. Rouam \& Cie, 1892, p. 311. Ademais, cotejou-se com a tradução inglesa Discourse on Cicero. Trad. David Fott. Political Theory, v. 30, n. 5, p. 733-737, out. 2002 e com a espanhola Discurso sobre Cicerón. Trad. Christian Felipe Pineda Pérez. Praxis Filosófica, nueva serie, n. 39, p. 211-217, jul./dez. 2014. Optamos por inserir entre colchetes a numeração original das linhas. [N.T.]

$5 \mathrm{Eu}$ fiz esse discurso em minha juventude. Ele poderia tornar-se bom, se eu lhe retirasse o ar de panegírico. É necessário, além disso, dar um mais longo detalhe das obras de Cícero, ver as cartas sobretudo, e entrar mais adiante nas causas da ruína da República e nos caracteres de César, de Pompeu, de Antônio.

6 Trata-se de Alexandre, o Grande, biografado pelo mencionado Quinto Cúrcio Rufo. Ver Historia de Alejandro Magno. Trad. Francisco Pejenaute Rubio. Madrid: Gredos, 1986. [N. T.]

7 Trata-se de uma tradução livre de Philippicae II, 24. Cf. Filípicas. Trad. Juan Bautista Calvo. Barcelona: Planeta, 1994, p. 37.

8 Julium Sidus.

9 Segunda Filípica.

10 Sétima Controvérsia. 